\title{
Reproductive cycle of the Neotropical cichlid yellow peacock bass Cichla kelberi: A novel pattern of testicular development
}

\author{
Diógenes Henrique de Siqueira-Silva ${ }^{1}$, Carlos Alberto Vicentini², \\ Alexandre Ninhaus-Silveira ${ }^{3}$ and Rosicleire Veríssimo-Silveira ${ }^{3}$
}

The present study describes the testicular maturation phases (associating the germ cells development and the morphological changes suffered by the germinal epithelium along the whole year), and the testicular morphology in the yellow peacock bass Cichla kelberi, relating it to other species. For this purpose, 78 specimens were studied according conventional techniques of light microscope. The testes in C. kelberi were classified as unrestricted spermatogonial lobular, an apomorphic characteristic in the recent groups of Teleost. Furthermore, were defined five testicular maturation phases: Preparatory phase; Early Germinal Epithelium Development; Mid Germinal Epithelium Development; Late Germinal Epithelium Development and; Regression. Similar classifications were described to other species indicating that the testicular classifications based on this propose, can be applied to lots of fishes. However, besides it similarity, the testicular reproductive cycle of $C$. kelberi follows a different pattern in the Regression phase, on which the gonadal restructuration and the spermatogonial proliferation gathers at the same time. So, the testes in $C$. kelberi never return to the Preparatory phase to start a new reproductive cycle, being this one present only at the first reproductive cycle in this species. This fact also explains the absence of individuals totally spent after their first reproductive cycle.

O presente estudo descreve as fases de maturação testicular (associando o desenvolvimento das células germinativas e as alterações morfológicas sofridas pelo epitélio germinativo ao longo do ano), e a morfologia testicular do tucunaré amarelo Cichla kelberi, relacionando a outras espécies. Com este propósito, 78 indivíduos foram estudados de acordo com técnicas convencionais para microscopia de luz. Os testículos em C. kelberi foram classificados como lobular espermatogonial irrestrito, uma característica apomórfica encontrada nos grupos recentes dos teleósteos. Além disso, cinco fases de maturação testicular foram definidas para C. kelberi: Fase Preparatória; Desenvolvimento Inicial do epitélio germinativo; Desenvolvimento Intermediário do epitélio; Desenvolvimento Final do epitélio germinativo e Regressão. Classificações similares foram descritas para outras espécies, indicando que a classificação gonadal baseada nesta proposta, pode ser aplicada a muitas espécies de peixes. Entretanto, apesar desta similaridade, o ciclo reprodutivo testicular de $C$. kelberi segue um padrão diferente na fase de Regressão, na qual a reestruturação gonadal e a proliferação espermatogonial ocorrem ao mesmo tempo. Deste modo, os testículos em $C$. kelberi nunca retornam à fase Preparatória para começar um novo ciclo reprodutivo nesta espécie. Este fato também explica a ausência de indivíduos totalmente esgotados após seu primeiro ciclo reprodutivo.

Key words: Germinal epithelium, Gonadal maturation, Reproductive phases, Spermatogenesis, Testes.

\section{Introduction}

Morphological studies of the Teleost gonads have been conducted for years aiming the identification of the reproductive biology aspects of this group, such as the annual reproductive cycle, which is based on the gonadal maturation phases of species (Selman \& Wallace, 1996; Grier \& Taylor 1998; QuagioGrassiotto et al., 2011). The analyses of the testicular maturation in fishes is performed according the association between the developmental stages of germ cells, present in the germinal epithelium (GE) in each moment of the cycle, and the morphological changes suffered by the germinal epithelium

\footnotetext{
${ }^{1}$ UNESP - Universidade Estadual Paulista "Júlio de Mesquita Filho", Câmpus de São José do Rio Preto, Programa de Pós-Graduação em Biologia Animal. Rua Cristóvão Colombo, 2265, Jardim Nazareth, 15054-000 São José do Rio Preto, São Paulo, Brazil. siqueira.diogenes@gmail.com

${ }^{2}$ UNESP - Universidade Estadual Paulista “Júlio de Mesquita Filho”, Câmpus de Bauru, Departamento de Ciências Biológicas, LAMOA - Laboratório de Morfologia de Organismos, Av. Eng. Luiz Edmundo Carrijo Coube, Nº14-01, 17033-360 Bauru, São Paulo, Brazil. carlosav@fc.unesp.br

${ }^{3}$ UNESP - Universidade Estadual Paulista "Júlio de Mesquita Filho", Câmpus de Ilha Solteira, Departamento de Biologia e Zootecnia, L.I.NEO - Laboratório de Ictiologia Neotropical, Av: Brasil, Centro, 56, 15385-000 Ilha Solteira, São Paulo, Brazil. ninhaus@bio.feis.unesp.br; rosiverissimo@bio.feis.unesp.br
} 
throughout the year. These changes allow the classification of the germinal epithelium in continuous, characterized by a continuous population of Sertoli and germ cells, and discontinuous, in which occurs the germ cells waste at the moment of sperm liberation into the seminiferous tubules lumen (Grier \& Taylor, 1998; Grier, 2002; Grier \& Aranzabal, 2009).

This methodology has been widely spread, showing its efficiency for the definition of the reproductive phases in several fish species, even to those that belong to different orders, as the Perciformes, and Characiformes ones (Grier \& Taylor, 1998; Brown-Peterson \& Warren, 2001; Brown-Peterson et al., 2002; Cinquetti \& Dramis, 2003; Lo Nostro et al., 2003; Batlouni et al., 2006). Furthermore, beyond its traditional utilization, the morphological characteristics of the gonads also help to clarify the phylogenetic relationship among bone fishes, as previously proposed by Parenti \& Grier (2004), because the testicular structure found in fish species (anastomosing tubular, restricted spermatogonial lobular and unrestricted spermatogonial lobular) (Grier \& Aranzabal, 2009), is directly related to the taxa each one occupies into the evolutionary scale.

Belonging to the Cichla genus, which joins 15 fish species known by the coloration and meristic pattern, the yellow peacock bass Cichla kelberi Kullander \& Ferreira, 2006 is native from the Araguaia and lower Tocantins Rivers. However, nowadays this species also can be found in several rivers and reservoirs along the country, where it was introduced for farming and restocking programs (Kelber, 1999; Chellappa et al., 2003; Kullander \& Ferreira, 2006). Cichla kelberi species was recently classified and is different from the other Cichla species by the presence of small clear spots in the pelvic and anal fins and in the lower lobe on the caudal fin (Kelber, 1999; Chellappa et al., 2003; Kullander \& Ferreira, 2006). Apart from being highly appreciated in the culinary, this species became the fishing national symbol, and it may achieve total lengths between 40 and $45 \mathrm{~cm}$. So, the aim of this study was to describe the testicular maturation phases and the testicular morphology of C. kelberi, relating it to other species described in literature.

\section{Material and Methods}

In this study 78 male individuals of the yellow peacock bass Cichla kelberi were collected between the period from March 2009 to February 2010, by fishing rod and hook (reel and roulette) from the Pernilongo lake $\left(20^{\circ} 29^{\prime} 11.93\right.$ "S $\left.51^{\circ} 25^{\prime} 33.27^{\prime \prime} \mathrm{W}\right)$ and Ferradura Island $\left(20^{\circ} 28^{\prime} 27.11^{\prime \prime} \mathrm{S}\right.$ $51^{\circ} 25^{\prime} 54.53^{\prime} \mathrm{W}$ ), both localized in the Jupiá reservoir, Paraná River, in Ilha Solteira municipality, São Paulo State, Brazil. After being anesthetized in alcoholic solution of Benzocaine ( $0.5 \mathrm{~g}$ of Benzocaine in $5 \mathrm{~mL}$ of absolute alcohol), the measurement of the total length (LT, cm), standard length (LS, cm), body weight (Wb, g), and gonadal weight (Wg, g) of each specimen was performed. The body and gonadal weight values were used to calculate the gonadosomatic index (GSI) following the formula: GSI $\%=(\mathrm{Wg} / \mathrm{Wb})^{*} 100$. Fishes were identified and a group of voucher individuals was deposited in the colection of fishes of DZSJRP Laboratório de Ictiologia Departamento de Zoologia e Botânica IBILCE/ UNESP under the numbers $8833,8843,8872$ and 8946 .

For histological preparation, the fishes had their testes removed, fragmented (transversal and longitudinal sections) and fixed in $4 \%$ paraformaldehyde and $2 \%$ glutaraldehyde in

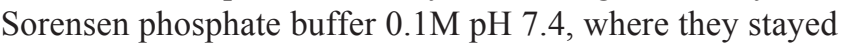
for at least 24 hours. Then, they were dehydrated in alcoholic solution in growing concentration and embedded in glycolmetacrylate historesin (Technovit 7100), sectioned in $3.0 \mathrm{~mm}$ of thickness in microtome equipped with glass razor (LEICA RM 2245) and stained with Hematoxilin and Eosin, besides being submitted to the Reticulin reaction. All material was analyzed in the light microscope Olympus - CX 41 and documented with photographic machine MOTICAN 2500 5.0 MPixel USB 2.0.

\section{Results}

The average total length of C.kelberi specimens, collected in this study, was $32.36 \mathrm{~cm}$ (the biggest individual measured $43 \mathrm{~cm}$ and the smallest one $19.5 \mathrm{~cm}$ ), while the average weight was $486.8 \mathrm{~g}$ (with maximum weight of $1180 \mathrm{~g}$ and minimum of $100 \mathrm{~g})$.

In C. kelberi the testes are paired elongated organs, dorsally situated on coelomic cavity, under the kidneys. They are lined by a mesothelium and internally covered by the tunica albuginea, which sends projections into the testes, forming lobules that ended blind in the testicular periphery (distal and dorsal region) (Figs. 1a, d). Inside the lobules a testicular germinal epithelium is present, being characterized by the strict association between the somatic Sertoli cells and germ cells, which can be found isolated (undifferentiated spermatogonia), or into cysts. Each cyst consists of a group of germ cells interconnected by cytoplasmic bridges, at the same developmental stage, which are totally surrounded by cytoplasmic process of Sertoli cells (Figs. 1, 5c, 6c, 7c). This association between Sertoli cells and germ cells through the epithelium characterizes it as a continuous germinal epithelium (Fig. 5b), however, as the spermatozoa are formed and released from the cysts into the lobular lumen, only Sertoli cells are found in the epithelium, characterizing it as a discontinuous germinal epithelium (Figs. 6a-c).

The lobules continue from the blind region in direction to the ventral region of the testis (proximal region), where they bifurcate forming a distinct region named anastomosing region. The anastomosing region, on the other hand, opens in an area of storage and conduction of spermatozoa called main testicular duct (Fig. 1c).

The testicular morphological evaluation of the specimens caught during the reproductive cycle of $C$. kelberi allowed the definition of five testicular maturation phases (Fig. 2):

I - Preparatory. The Preparatory phase initiates the testicular reproductive cycle in C. kelberi. Different from the Immature testicle, which presents just primary spermatogonia in reduced number into the germinal 


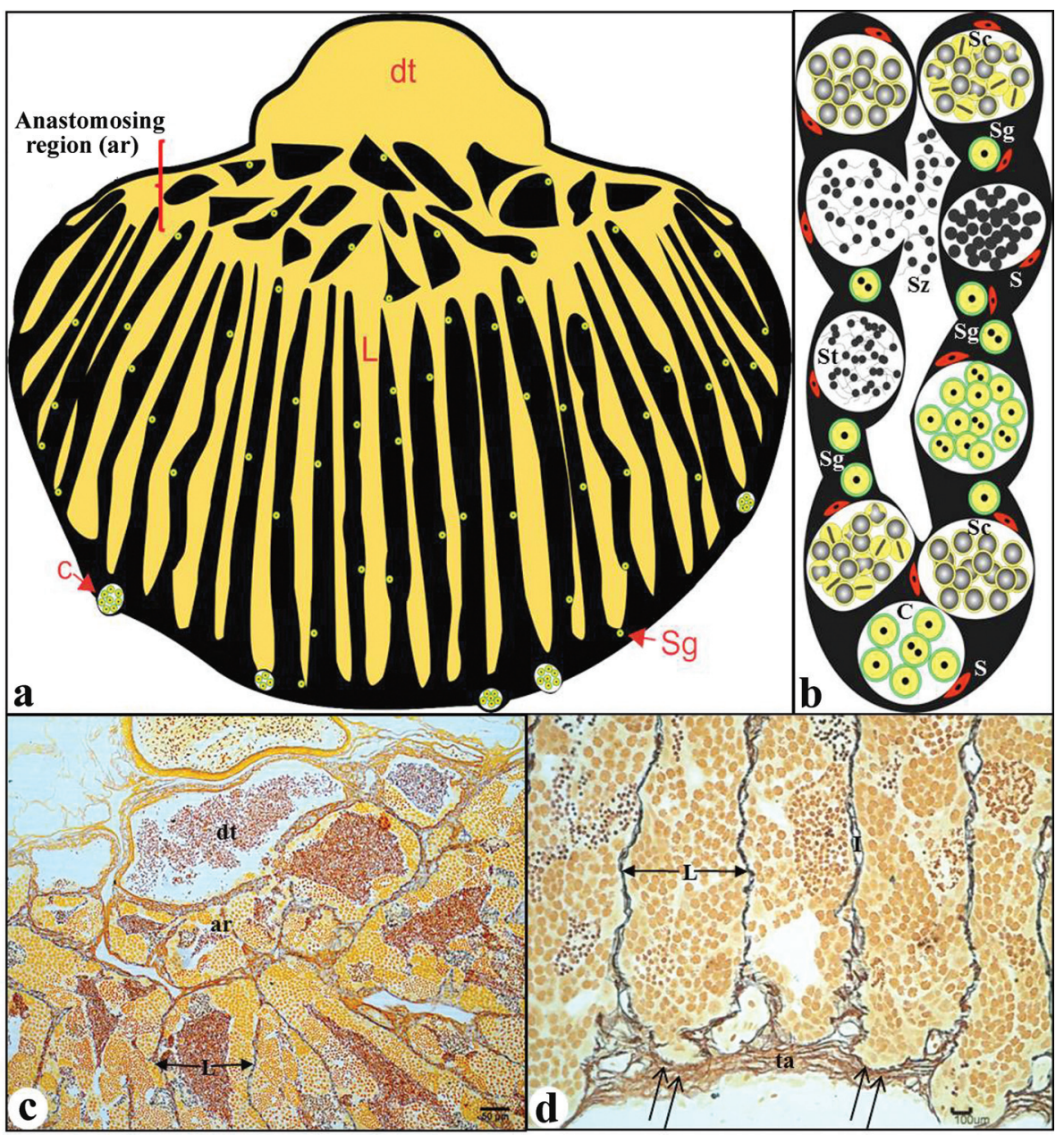

Fig. 1. Testicular structure of C. kelberi in transversal section. (a) Testis draft highlighting the different regions. (b) A lobule representation, highlighting the cystic type spermatogenesis and the unrestricted distribution of spermatogonia. (c) Testis ventral region, showing the main testicular duct (dt), anastomosing region (ar) and the beginning of the lobular region (L). Reticulin reaction. (d) Testis dorsal region, highlighting the blind end (double arrow) of the testicular lobules, which are formed by the connective tissue septa sent by tunica albuginea (ta). Reticulin reaction. $\mathrm{c}$ - spermatogonial clusters; I - interstice; S Sertoli cell; Sc - spermatocyte; Sg - spermatogonia; St - spermatid.

epithelium, this phase is characterized, principally, by a big proliferation of spermatogonial cells in the testes, forming a continuous population of primary and secondary spermatogonia involved by cytoplasmic process of Sertoli cells (Figs. 4c-d). These germ cells undergo successive divisions, resulting in mitotic figures, which can be observed in this phase (Fig. 4c). But, at this moment, cysts formed by primary or secondary spermatocytes and spermatids are not found in the testes. Moreover, in this phase it is also impossible to identify the lumen of the seminiferous tubules and the main testicular duct using light microscopy, which by the way, hampers the definition of the lobular structure, characteristic of the testes in this species (Figs. 4c-d). The mean value for the GSI of individuals in this phase is 0.034 (Fig. 9).
II - Early Germinal Epithelium Development (Early GE Development). In this phase the germinal epithelium presents germ cells cysts along all its extension, from the periphery to the main testicular duct (continuous germinal epithelium), which is, in this phase, filiform and little visible, showing a narrow light (Fig. 5a). The cysts found in the testicular lobules have germ cells in all developmental stages (secondary spermatogonia, primary and secondary spermatocytes and spermatids), getting actively divided by the mitotic and meiotic processes throughout the spermatogenesis (Figs. 5b-d). The cysts of primary spermatocytes are the most frequent whereas the undifferentiated spermatogonia (found isolated) are rarely observed in this phase. The lobular lumen, which is initially imperceptible by light microscopy, becomes visible as the phase progresses and the spermatogenic cysts break, 


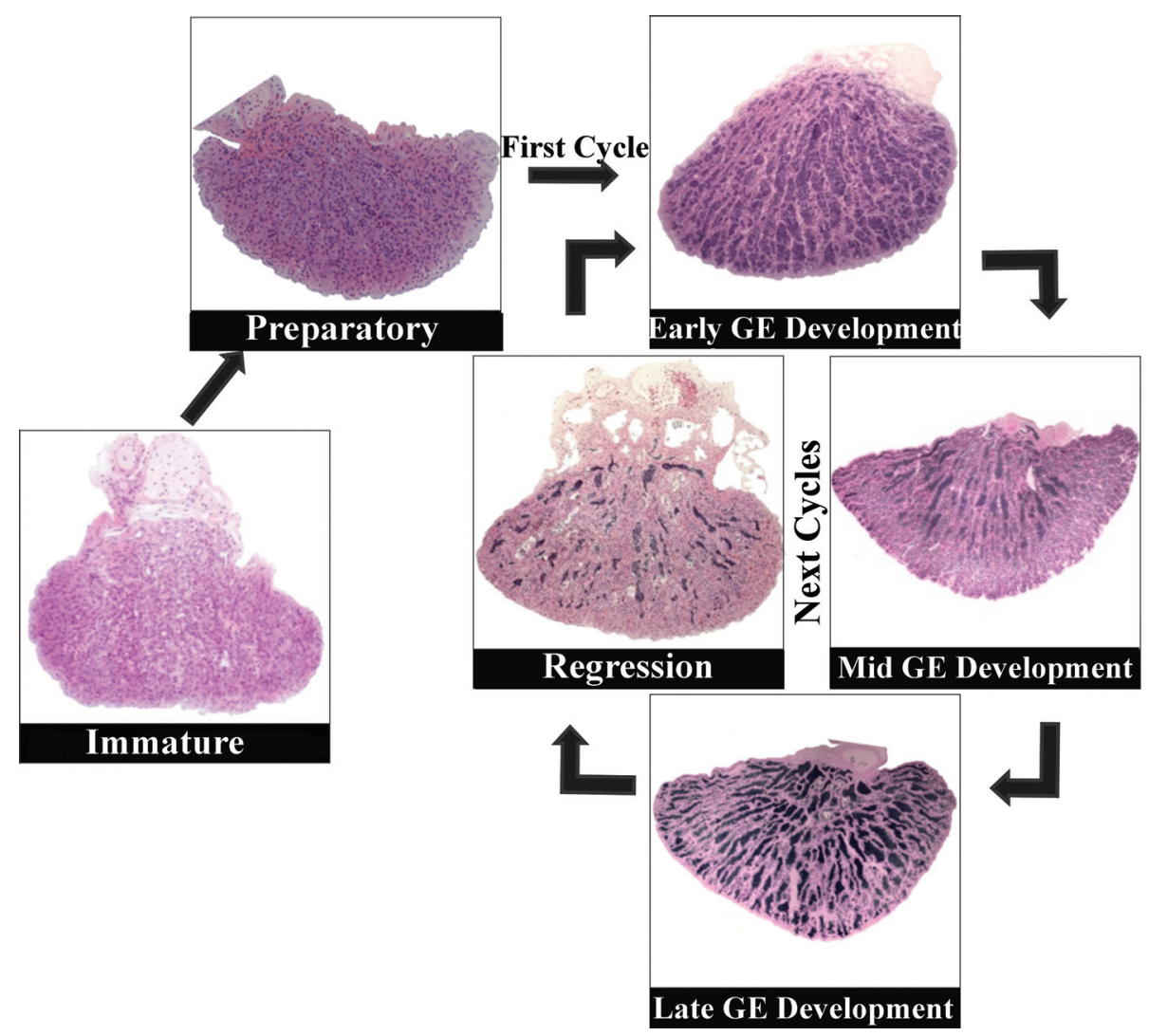

Fig. 2. Gonadal development Phases of $C$. kelberi along the reproductive cycle. H.E. stain.

releasing the spermatozoa to the lumen. Despite the breaking of some cysts, the germinal epithelium still remains continuous in this reproductive cycle phase (Fig. 3). At the blind region of some lobules, in the testicular periphery, spermatogonial clusters are observed exhibiting few cells inside them (Fig. $5 \mathrm{~d})$. The mean value for the GSI of individuals in this phase is 0.2293 (Fig. 9).

III - Mid Germinal Epithelium Development (Mid GE Development). This reproductive phase is characterized by the beginning of the germinal epithelium discontinuity in the anastomosing region (Figs. 6a-b). As the testicular development progresses, the discontinuity in the germinal epithelium is observed in the lobules near the main testicular ducts, remaining, however, continuous in the testicular periphery (Figs. 6b-d). In this period the spermatogenesis in the anastomosing region becomes increasingly reduced and the spermatozoa volume inside the testicular lumen increases. This way, both the anastomosing region and the main testicular duct, start to operate as a region for sperm storage. In spite of germ cells cysts scarcity in the lobules at the proximal region, in the testicular periphery lobules still present lots of cysts with germ cells into spermatogenesis (Figs. 6c-d). Similarly to the previous phase, the testes of the specimens observed here also have scarce undifferentiated spermatogonia throughout the gonad and in the peripheral spermatogonial clusters, which get absent at the end of this maturation phase (Fig. 6d). The mean value for the GSI of individuals in this phase is 0.259 (Fig. 9).

IV- Late Germinal Epithelium Development (Late GE Development). The final development phase in C. kelberi starts when the discontinuity of the germinal epithelium reaches the peripheral testicular region (the blind region of the lobules), which does not occur simultaneously for all lobules (Fig. 7b). Therefore, at the beginning of this phase many lobules still present continuous germinal epithelium in their distal portion. However, as the testicular maturation process advances, the discontinuity in the lobules also progresses, until be observed along the entire testicular germinal epithelium (Fig. 7d). At the Late GE Development phase, the anastomosing region, in which the spermatogenesis was ceased, and the main testicular duct store a big concentration of sperm (Fig. 7a). Even in the absence of mitotic and meiotic divisions at the germinal epithelium in the anastomosing region and in the lobular portions near it; and the big spermatozoa volume along the entire testicle, also in this phase is possible to observe throughout the lobules many spermatogenic cysts in cellular division (Figs. 7b-c). 


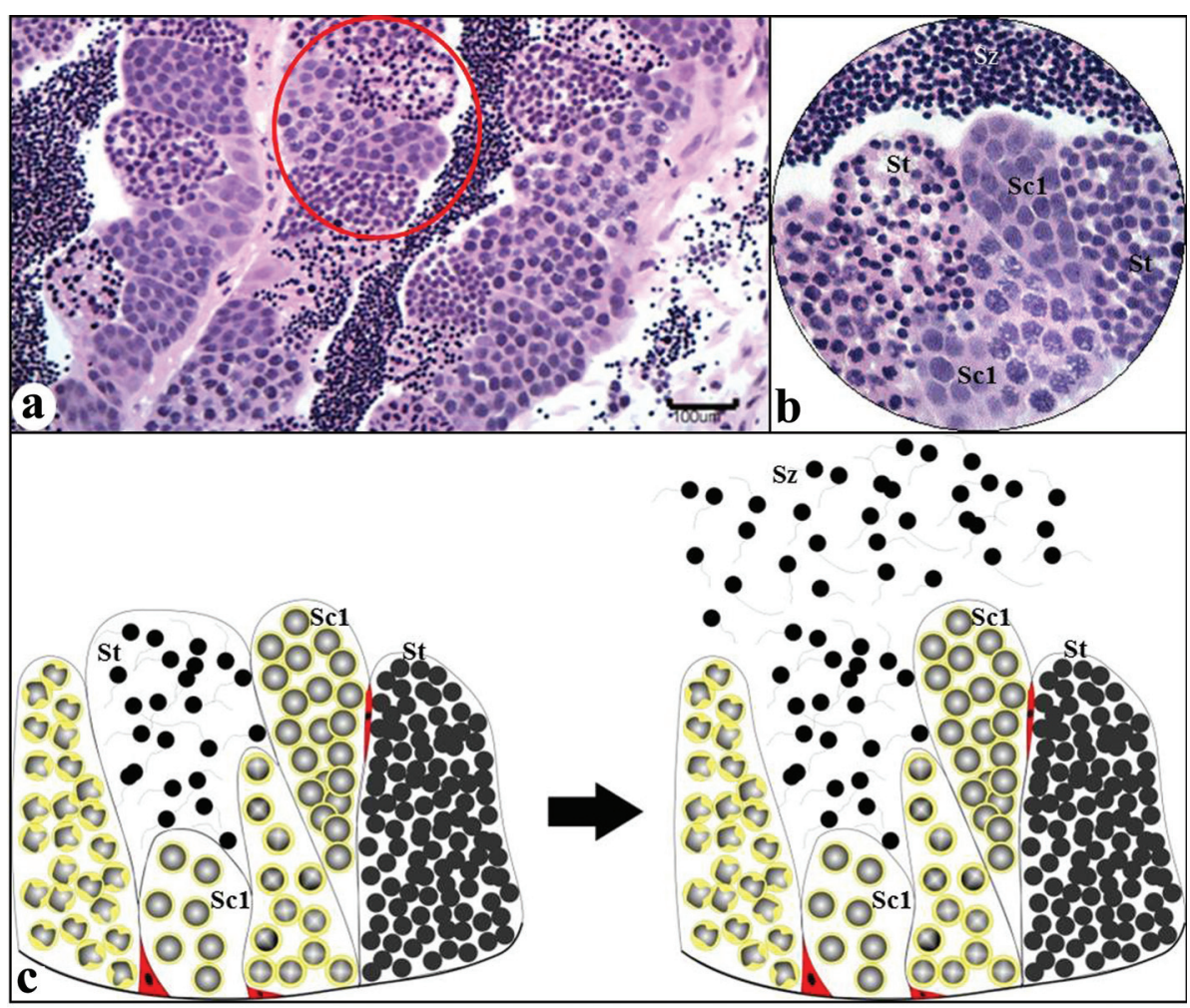

Fig. 3. Structure of the germinal epithelium in C. kelberi. (a and b) germinal epithelium highlighting the spermatogenic cysts in distinct layers. H.E. stain. (c) Outline highlighting the maintenance of a continuous germinal epithelium after the higher layers cysts break. Sc1 - primary spermatocyte; St - spermatid; Sz - spermatozoa.

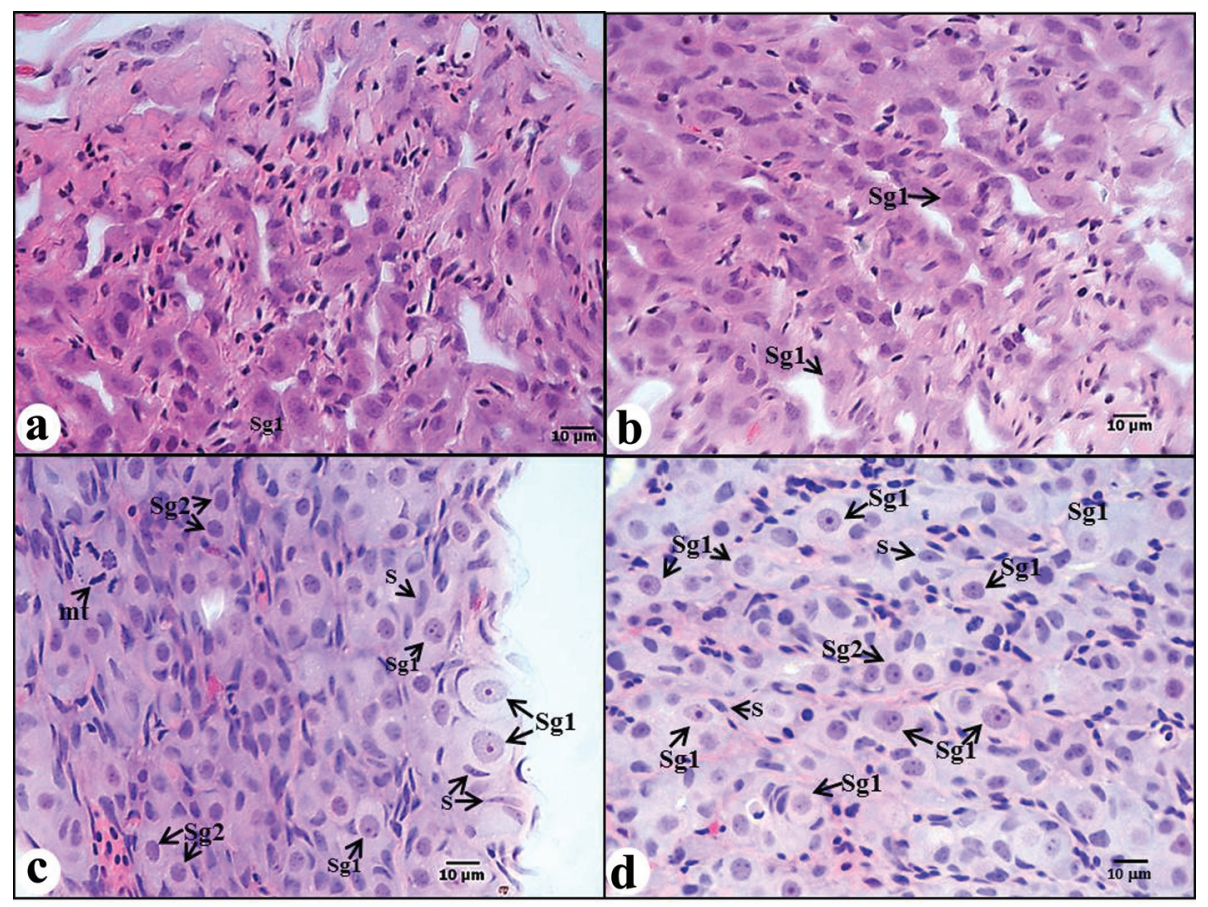

Fig. 4. Testicular morphological characteristics of the initial phases of $C$. kelberi gonadal development. (a) and (b) Immature phase: germinal epithelium showing a reduced number of primary spermatogonia ( $\mathrm{Sg} 1)$. (c) and (d) Preparatory phase: presence of lots of primary spermatogonia and cysts of secondary spermatogonia (Sg2). Mitotic figures are also observed in this phase, highlighting the spermatogonial proliferation (arrow). 


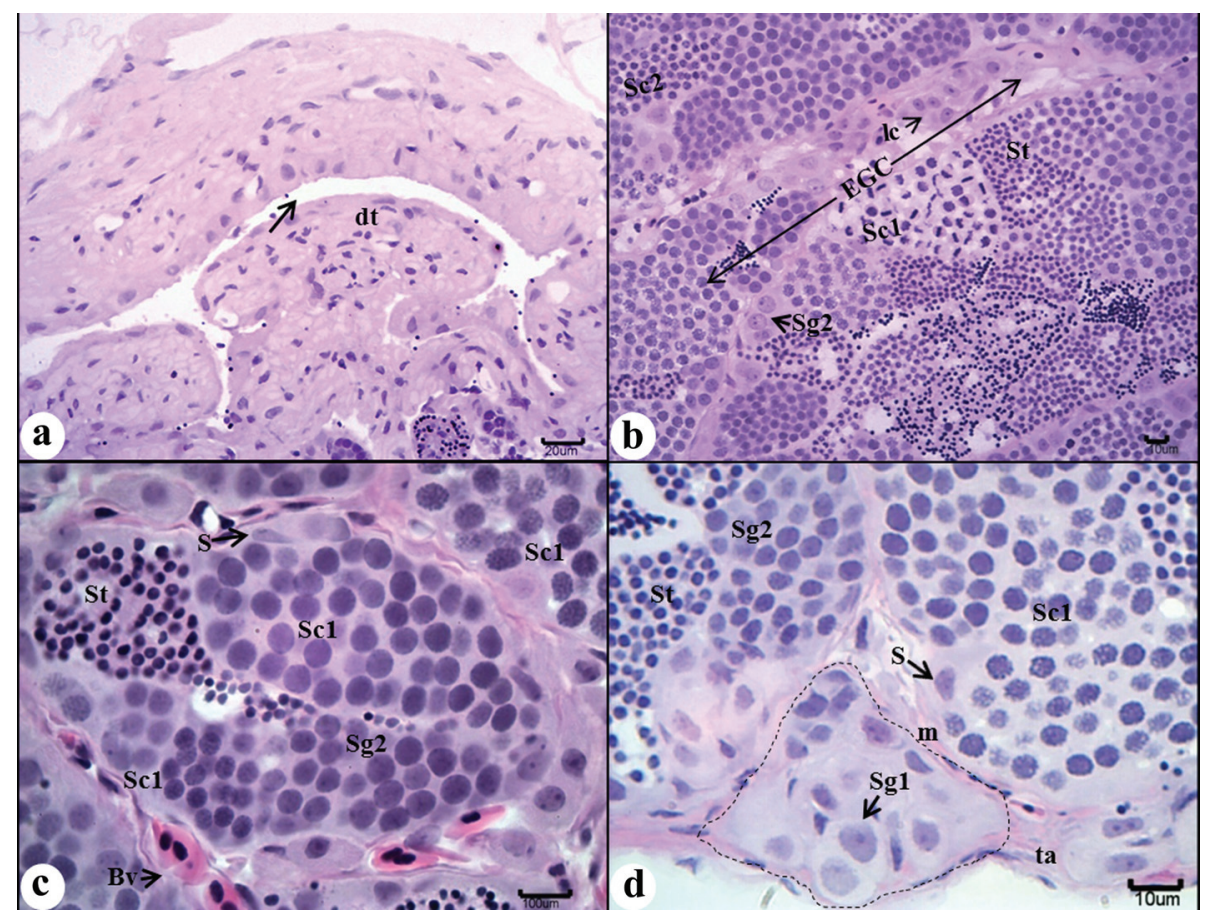

Fig. 5. Testicular morphological characteristics of Early GE Development phase in C. kelberi. (a) Main testicular duct region (dt), highlighting the narrow light (arrow). (b) Testicular lobules with continuous germinal epithelium (Egc) and germ cells cysts in different phases of spermatogenesis. (c) Germ cells cysts in different phases of spermatogenesis. (d) Distal lobular region, highlighting the germ cells clusters (dotted line). Bv - blood vessels; S - Sertoli cell; Sc1 - primary spermatocysts ; Sg1 - primary spermatogonia; $\mathrm{Sg} 2$ - secondary spermatogonia; St - spermatids; ta - tunica albuginea. H. E. stain.

Undifferentiated spermatogonia can be seen along the entire gonad, as well as in the testicular periphery (Fig. 7d), where they are isolated among cysts or constitute the peripheral clusters, which reappear in the end of this reproductive phase. At the end of this phase melanomacrophage centers are also observed (Fig. 7d). The mean value for the GSI of individuals observed in this phase is 0.296 (Fig. 9).

V- Regression. The Regression in C. kelberi can be defined by multiple characteristics. Among them we can highlight: discontinuity in every testicular lobules (Fig. 8c); higher evidence of the connective tissue that form the interstitial compartment; spermatogonial proliferation along the entire testicular extension, principally at the peripheral clusters, which are very common in this phase (Fig. 8d); residual spermatozoa are spread throughout gonadal extension (Figs. 8b-d); but, principally, by the simultaneous testicular development, evidenced by the presence of cysts in spermatogenic process, and the structural reorganization, seen by the presence of cells showing pyknotic nuclei, residual spermatozoa, innumerous Sertoli cells phagocytizing residual bodies from the previous reproductive cycle, and the continuously increase of melanomacrophage centers volume (Figs. 8a-d).
At the Regression phase, the C. kelberi testicle (main testicular duct, lobules and interstitial compartment) shows an irregular and tortuous outline, giving it a flabby appearance. During this phase of testicular maturation, the undifferentiated spermatogonia restart their proliferation by successive mitotic divisions, giving origin to new spermatogenic cysts. At the Regression end, the testes are replete of spermatogenic cysts and the animal is ready to start a new reproductive cycle, returning to the Early GE Development phase (Fig. 2). The mean value for the GSI of individuals in this phase is 0.0894 (Fig. 9).

\section{Discussion}

The morphological characterization of $C$. kelberi testes as lobular type, phylogenetically corroborates with Parenti \& Grier (2004) results, who propose this testicular type as a synapomorphic character present in all surviving Neoteleost, just like the results obtained for other species of the orders Perciformes, Scorpaeniformes and Synbranchiformes, which represent more derived taxa when compared to Characiformes, Cypriniformes, and Siluriformes, whose testes were classified as anastomosing tubular (Selman \& Wallace, 1986; BrownPeterson et al., 2002; Cinquentti \& Dramis, 2003; Vicentini et 


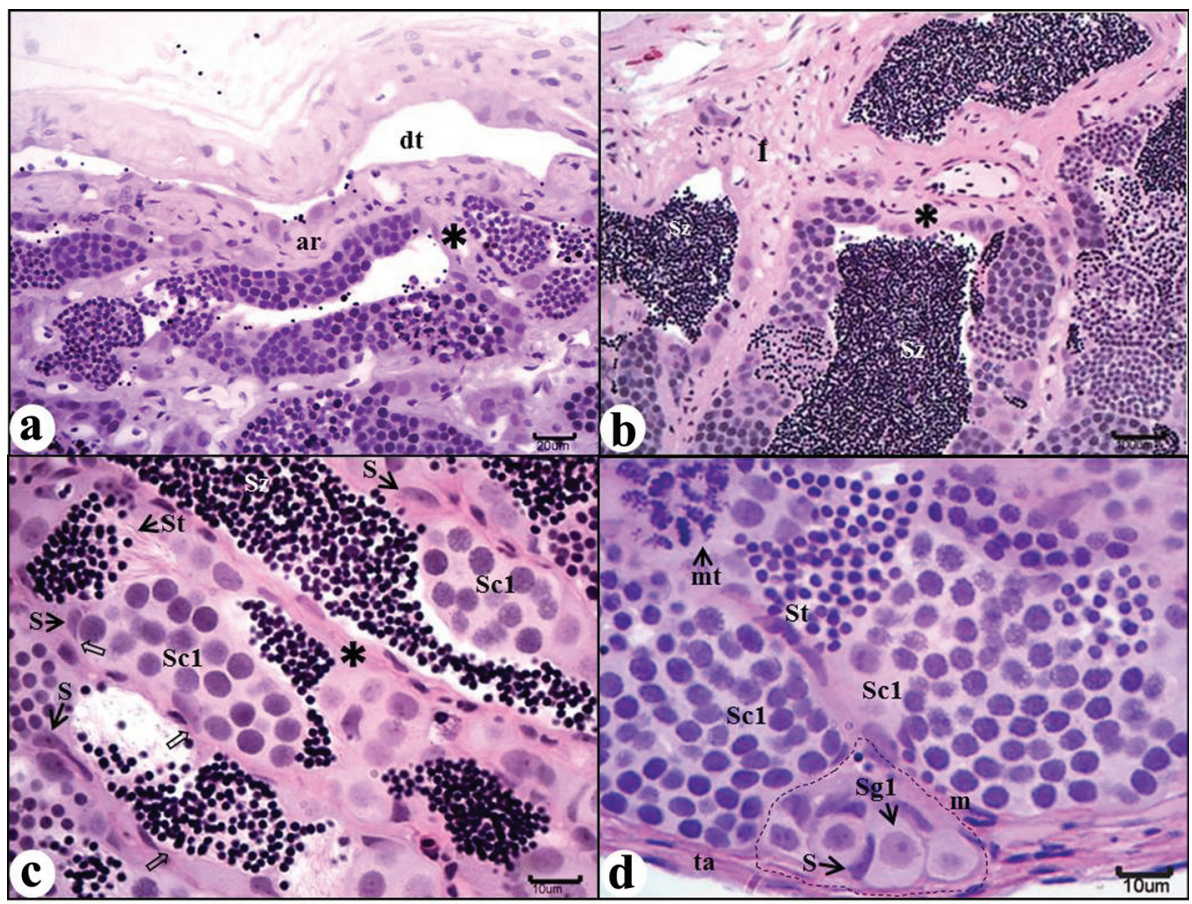

Fig. 6. Testicular morphological characteristics of Mid GE Development phase in C. kelberi. (a and b) Testicular anastomosing region, highlighting the beginning of the germinal epithelium discontinuity (asterisk), in both the anastomosing region and lobules near the main testicular ducts. (c) Discontinuous germinal epithelium, with cysts in different development stages and lots of sperm (Sz) in the lobular lumen. (d) Peripheral lobular region (dorsal) highlighting the continuous germinal epithelium and clusters of primary spermatogonia (dotted line). ar - anastomosing region; $\mathrm{dt}$ - main testicular ducts; I - interstice; $\mathrm{m}$ - basal membrane; mt - metaphase; S - Sertoli cell; Sc1 - primary spermatocysts ; Sg1 - primary spermatogonia; Sg2 - secondary spermatogonia; St - spermatids; ta - tunica albuginea; cytoplasmic extension (hollow arrow). H.E. stain.

al., 2001; Muñoz et al., 2002; Lo Nostro et al., 2003b; Arias et al., 2004, Dadzie \& Abou-Seedo, 2004; Parenti \& Grier, 2004; Thacker \& Grier, 2005; Nobrega \& Quágio-Grassiotto, 2007; Spadella et al., 2008; Matta et al., 2009; Leal et al., 2009; Martins et al., 2010; Muñoz et al., 2010).

As most of the existing taxa, C. kelberi testes are also classified as unrestricted spermatogonial, because of the distribution of the spermatogonia in the lobules. Hence, in this species the testes are classified as unrestricted spermatogonial lobular, an apomorphic characteristic found at the recent groups, in exception to Atherinomorpha series and the small Schindler's fish Schindleria praematura (Schindler, 1930), which present the restricted spermatogonial lobular type one, characterized by the restriction of spermatogonia at the distal portion of the lobules (Parenti \& Grier, 2004).

The reproductive phases in C. kelberi are similar to those initially used by Grier \& Taylor (1998) to define the annual reproductive cycle in the common snook Centropomus undecimalis (Bloch, 1792). However, differently from their observations, in the initial steps of the testicular development in C. kelberi, the continuity of the germinal epithelium is maintained, even occurring spermiation in some spermatogenic cysts. This fact just occurs because of the germ cells cysts overlap, forming a germinal epithelium in layers. Consequently, even after the spermiation of the superior spermatogenic cysts, the presence of the basal ones ensures the germinal epithelium maintenance in C. kelberi when the individuals are in the Early GE Development phase, characterized by the presence of an epithelium totally continuous.

Similar classifications, based on the methodology adopted in the present study, were also described for spotted weakfish Cynoscion nebulosus (Cuvier, 1830), cobia Rachycentron canadum (Linnaeus, 1766), common goby Padogobius martensii (= Padogobius bonelli Bonaparte, 1846) and marbled swamp eel Synbranchus marmoratus Bloch, 1795 (Brown-Peterson \& Warren, 2001; Brown-Peterson et al., 2002; Cinquentti \& Dramis, 2003; Lo Nostro et al., 2003). These results indicate that the testicular classification based on this proposal, can, probably, be applied to a great variety of fish species with satisfactory results (Cinquentti \& Dramis, 2003; Lo Nostro et al., 2003; Batlouni et al., 2006).

However, differently from Grier \& Taylor (1998) founds in C. undecimalis. In C. kelberi the Regressed phase, here called Preparatory, which is characterized by the spermatogonial (primary or secondary) presence in the germinal epithelium (Grier, 2002), just occurs at the beginning of its first 


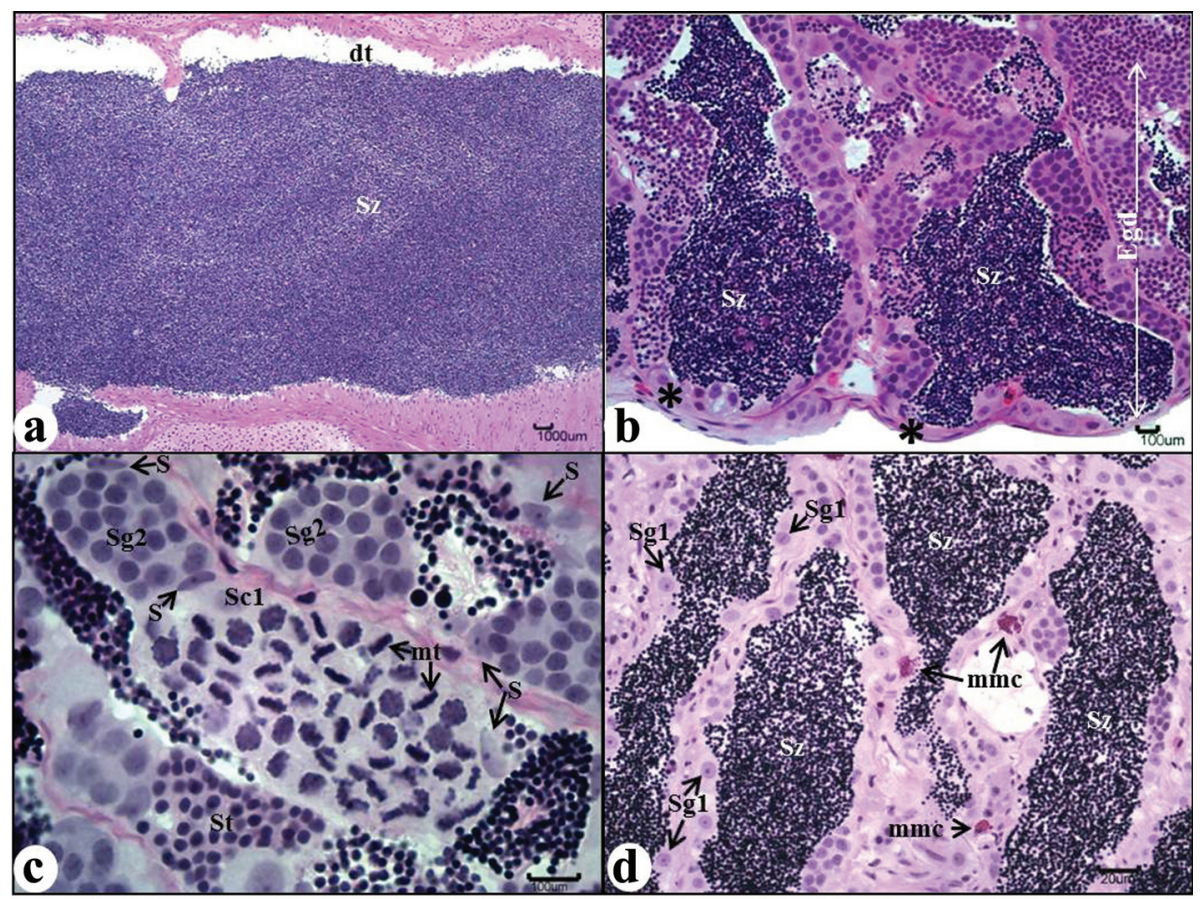

Fig. 7. Testicular morphological characteristics of Late GE Development phase in C. kelberi. (a) Longitudinal section of the main testicular duct (dt). (b) Germinal epithelium discontinuity in the distal region of the testicular lobules (asterisk). (c) Spermatogenic cysts in different development phases, highlighting the spermatocytes cyst in metaphase (mt) of the first meiotic division. (d) Discontinuity of the germinal epithelium along the testicle. H.E. stain. Egd - discontinuous germinal epithelium; mmc - melano-macrophage centers; S - Sertoli cell; Sc1 - primary spermatocysts ; Sg1 -primary spermatogonia; Sg2 - secondary spermatogonia cysts; St - spermatids cysts; Sz - sperm. H.E. stain.

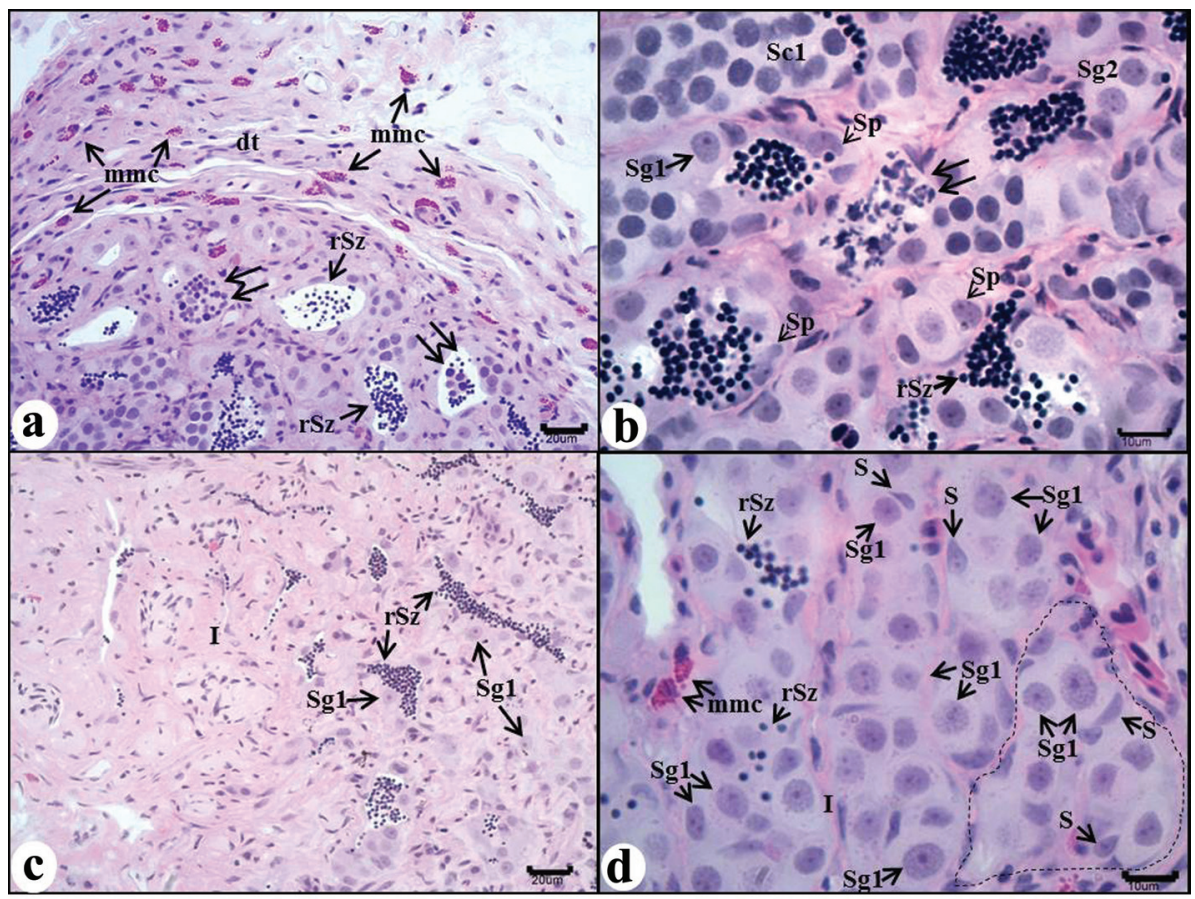

Fig. 8. Testicular morphological characteristics of the Regression phase in C. kelberi. (a) Testicular proximal region, highlighting the big volume of melano-macrophage centers ( $\mathrm{mmc}$ ). (b) Gonad in restructuration with details to the Sertoli cells phagocytizing (Sp) the residual sperm (rSz), and the apoptotic cells (double arrow). (c) Transversal section along the testis in Regression. (d) Testicular periphery (dorsal region) highlighting the intense proliferation of primary spermatogonia in this region ( $\mathrm{Sg}$ ). primary spermatogonial cluster (dotted line); I - interstitial tissue; Sp - Sertoli cell in phagocytosis; Sc1 - primary spermatocysts ; Sg1 - primary spermatogonia; Sg2 - secondary spermatogonia. H.E. stain. 


\section{Literature Cited}

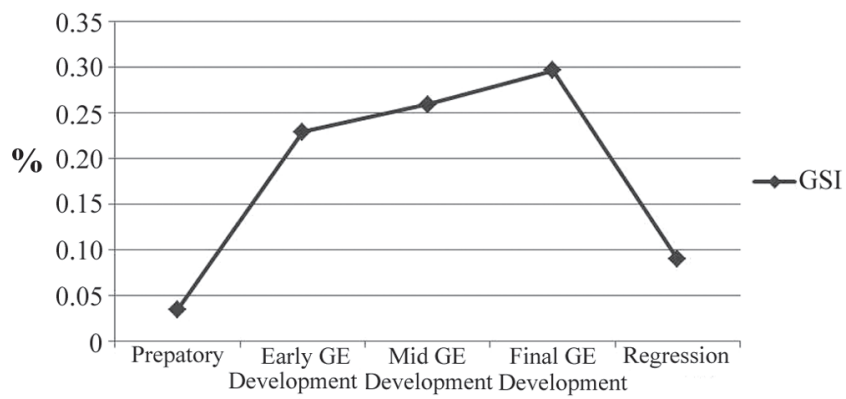

Fig. 9. Gonadosomatic Index (GSI) of the testicular maturation phases in C. kelberi.

reproductive cycle, moment in which the present spermatogonia suffer an intense mitotic proliferation, preparing the gonads to the beginning of a new reproductive cycle. The absence of $C$. kelberi specimens in this maturation phase after their first reproductive cycle in Jupiá Reservoir, is related to the reproductive manner adopted by the species, because at the end of each reproductive period, during the Regression phase, its testicle suffer an intense espermatogonial proliferation, giving origin to new germ cells and, consequently spermatocysts that repopulate the testes. This way, the Regression in C. kelberi gathers at the same phase, the testicular restructuration, which is characterized by the residual bodies phagocytosis, which seems to be related to the melano-macrophage centers, once occurs a considerable increase of their volume into the testes epithelium, and the spermatogonial proliferation. Therefore, the return to the Preparatory phase to start a new reproductive cycle does not occur in this species. The comparison between the GSI values of the Regression and Preparatory phases also helps to show this pattern, as the specimens with testes in Regression have new spermatogenic cysts, responsible for the sperm generation to the new reproductive cycle, the GSI values for these individuals will be always bigger than those ones in Preparatory phase, in which just spermatogonial cells are present in the testes. Moreover, as it was described for the peacock bass $C$. ocellaris Bloch \& Schneider, 1801 (Magalhães et al., 1996) and the blue peacock bass C. piquiti Kullander \& Ferreira, 2006 (Vieira et al., 2009), also in C. kelberi were not found individuals totally spent, which reinforces the hypotheses of inexistency of the Preparatory phase after its first reproductive cycle.

\section{Acknowledgments}

We would like to thank Fundação de Amparo à Pesquisa do Estado de São Paulo FAPESP by the financial support; E. R. Urzulin-Avanso and N. Avanso-Urzulin for their English help and L.I.NEO Group for its collaboration during the study development.
Arias, J. C., E. Zaniboni-Filho \& P. E. Cruz-Casallas. 2004. Ciclo testicular del Yamú, Brycon siebenthalae (Teleostei: Characidae) en cautiverio. Actual Biology, 26: 185-195.

Batlouni, S. R., E. Romagosa \& M. I. Borella. 2006. The reproductive Cycle of male catfish Pseudoplatystoma fasciatum (Teleostei: Pimelodidae) revealed by changes of the germinal epithelium an approach addressed to aquaculture. Animal Reproduction Science, 96: 116-132.

Brown-Peterson, N. J., H. J. Grier \& R. M. Overstreet. 2002. Annual changes in germinal epithelium determines male reproductive classes of the cobia. Journal of Fish Biology, 60: 178-202.

Brown-Peterson, N. J. \& J. W. Warren. 2001. The reproductive biology of the spotted seatrout, Cynoscion nebulosus, along the Mississip Gulf Coast. Gulf of Mexico Science, 1: 61-73.

Chellappa, S., M. R. Câmara, N. T. Chellappa, M. C. M. Beveridge \& F. A. Huntingford. 2003. Reproductive ecology of a Neotropical cichlid fish, Cichla monoculus (Osteichthyes: Cichlidae). Brazilian Journal of Biology, 63: 17-26.

Cinquetti, R. \& L. Dramis. 2003. Histological, histochemical, enzyme histochemical and ultrastructural investigations of the testis of Padogobius martensii between annual breeding seasons. Journal of Fish Biology, 63: 1402-1428.

Dadzie, S. \& F. Abou-Seedo. 2004. Testicular structure and spawning cycle in the silvery croaker, Otolithes ruber (Perciformes: Sciaenidae) in the Kuwaiti waters of the Arabian Gulf. Ichthyology Research, 51: 263-268.

Grier, H. J. 2002. The Germinal Epithelium: Its Dual Role in Establishing Male Reproductive Classes and Understanding the Basis for indeterminate Egg Production in Female Fishes. Institute of Marine Sciences, 53: 537-552.

Grier, H. J. \& M. C. U. Aranzabal. 2009. The Testis and Spermatogenesis in Teleost. Pp. 119-142. In: Jamieson, B. G. M. (Ed.). Reproductive Biology and Phylogeny of Fishes (Agnathans and Bony Fishes).Vol. 8, Part B. Enfield: Science Publishers.

Grier, H. J. \& R. G. Taylor. 1998. Testicular maturation and regression in the common snook. Journal of Fish Biology, 53: 521-542.

Kelber, D. 1999. Tucunaré uma paixão internacional. São Paulo: Arte \& Ciência.

Kullander, S. O. \& E. J. G. Ferreira. 2006. A review of the South American cichlid genus Cichla, with descriptions of nine new species (Teleostei: Cichlidae). Ichthyological Exploration of Freshwaters, 17: 298-398.

Leal, M. C., E. R. Cardoso, R. H. Nobrega, S. R. Batlouni, J. Bogerd, L. R. França \& R. W. Schulz. 2009. Histological and Stereological Evaluation of Zebrafish (Danio rerio) Spermatogenesis with an Emphasis on Spermatogonial Generations. Biology of Reproduction, 81: 177-187.

Lo Nostro, F., H. J. Grier \& G. A. Guerrero. 2003 a. Involvement of the Gonadal Germinal Epithelium During Sex Reversal and Seasonal Testicular Cycling in the Protogynous Swamp Eel, Synbranchus marmoratus Bloch, 1795 (Teleostei, Synbranchidae). Journal of Morphology, 257: 107-126.

Lo Nostro, F. L., H. J. Grier, F. J. Meijide \& G. A. Guerrero. 2003 b. Ultrastructure of the testis in Synbranchus marmoratus (Teleostei: Synbranchidae): the germinal compartment. Tissue \& Cell, 35: 121-132. 
Magalhães, A. L. B., Y. Sato, E. Rizzo, R. M. A. Ferreira \& N. Bazzoli. 1996. Ciclo reprodutivo do tucunaré Cichla ocellaris (Schneider, 1801), na represa de Três Marias, MG. Arquivo Brasileiro de Medicina Veterinária e Zootecnica, 48: 85-92.

Martins, Y. S., D. F. Moura, G. B. Santos, E. Rizzo \& N. Bazzoli. 2010. Comparative folliculogenesis and spermatogenesis of four teleost fish from a Reservoir in south-eastern Brazilian Actual Zoology (Stockholm), 91: 466-473.

Matta, S. L. P., M. C. M. Gomes \& D. R. Andrade. 2009. Reproductive Biology of the Oligosarcus argenteus (Gunther, 1864) Adult Males and Description of the Gonadal Maturation Stages. Brazilian Achieves of Biology and Technology, 52: 119126.

Muñoz, M., M. Casadevall \& S. Bonet. 2010. Gonadal structure and gametogenesis of Aspitrigla obscura (Pisces, Triglidae). Italian Journal of Zoology, 68: 39-46.

Muñoz, M., M. Sàbat, S. Mallol \& M. Casadevall, 2002. Gonadal Structure and Gametogenesis of Trigla lyra (Pisces: Triglidae). Zoological Studies, 41: 412-420.

Nobrega, R. H. \& I. Quagio-Grassiotto. 2007. Morphofunctional changes in Leydig cells throughout the continuous spermatogenesis of the freshwater teleost fish, Serrasalmus spilopleura (Characiformes, Characidae): an ultrastructural and enzyme study. Cell Tissue \& Research, 329: 339-349.

Parenti, L. R. \& H. J. Grier. 2004. Evolution and Phylogeny of Gonad, Morphology in Bony Fishes. Integrate and Comparative Biology 44: 333-348.
Quagio-Grassiotto, I., H. J. Grier, T. S. Mazzoni, R. H. Nobrega \& J. P. A. Amorim. 2011. Activity of the Ovarian Germinal Epithelium in the Freshwater Catfish, Pimelodus maculatus (Teleostei: Ostariophysi: Siluriformes): Germline Cysts, Follicle Formation and Oocyte Development. Journal of Morphology, 272: 1290-1306.

Selman, K. \& R. A. Wallace.1986. Gametogenesis in Fundulus heteroclitus. American Zoologist, 26: 173-192.

Spadella, M. A., C. Oliveira \& I. Quagio-Grassiotto. 2008. Morphology and Histology of Male and Female Reproductive Systems in the Inseminating Species Scoloplax distolothrix (Ostariophysi: Siluriformes: Scoloplacidae). Journal of Morphology, 269: 1114-1121.

Thacker, C. \& H. J. Grier. 2005. Unusual gonad structure in the paedomorphic teleost Schindleria praematura (Teleostei: Gobioidei): a comparison with other gobioid fishes. Journal of Fish Biology, 66: 378-391.

Vicentini, C. A., I. B. Franceschini-Vicentini, E. J. Benetti \& M. Orsi. 2001. Testicular ultrastructure and morphology of the seminal pathway in Prochilodus scrofa. Journal of Submicroscopic Cytology and Pathology, 33: 357-362.

Vieira, A. B. C., L. F. Salvador-Jr, R. M. C. Melo, G. B. Santos \& N. Bazzoli. 2009. Reproductive biology of the peacock bass Cichla piquiti (Perciformes: Cichlidae), an exotic species in a Neotropical reservoir. Neotropical Ichthyology, 7: 745-750.

Submitted March 19, 2013 Accepted June 19, 2013 by Clarice Fialho Published September 30, 2013 